\title{
Antitumor effects of bevacizumab in combination with fluoropyrimidine drugs on human oral squamous cell carcinoma
}

\author{
YASUTAKA ITASHIKI $^{1,2}$, KOJI HARADA ${ }^{1}$, TAKANORI TAKENAWA ${ }^{1}$, TARANNUM FERDOUS ${ }^{1}$, \\ YOSHIYA UEYAMA $^{3}$ and KATSUAKI MISHIMA ${ }^{1}$ \\ ${ }^{1}$ Department of Oral and Maxillofacial Surgery, Yamaguchi University Graduate School of Medicine, \\ Ube, Yamaguchi $755-8505 ;{ }^{2}$ Department of Dentistry and Oral Surgery, \\ National Hospital Organization Kanmon Medical Center, Shimonoseki, Yamaguchi 752-8510; \\ ${ }^{3}$ Department of Oral and Maxillofacial Surgery, Yamaguchi University, Ube, Yamaguchi 755-8505, Japan
}

Received July 26, 2020; Accepted January 5, 2021

DOI: $10.3892 / \mathrm{ol} .2021 .12991$

\begin{abstract}
Vascular endothelial growth factor (VEGF) serves an important role in new blood vessel formation or angiogenesis, which is a critical event in tumor growth and metastasis. Bevacizumab is a humanized monoclonal antibody against VEGF-A, whereas S-1 is a fluoropyrimidine antineoplastic agent that induces apoptosis in various types of cancer cells. The present study evaluated the antitumor effects of bevacizumab in combination with 5-fluorouracil (5-FU) or $\mathrm{S}-1$ against oral squamous cell carcinoma (OSCC) in vitro and in vivo. Two human OSCC cell lines were used, namely the high VEGF-A-expressing HSC-2 cells and the low VEGF-A-expressing SAS cells. MTT assay was used to evaluate the effect of bevacizumab and/or 5-FU against HSC-2 and SAS cell proliferation. Additionally, the antitumor effect of bevacizumab was evaluated alone and in combination with S-1 against HSC-2 tumors in nude mice. S-1 $(6.9 \mathrm{mg} / \mathrm{kg} / \mathrm{day})$ was administered orally every day for 3 weeks, and bevacizumab $(5 \mathrm{ml} / \mathrm{kg} /$ day $)$ was injected intraperitoneally twice per week for 3 weeks. Apoptotic cells in mouse tumors were detected using the TUNEL method, and cell proliferation and microvessel density (MVD) were determined by immunohistochemical staining of Ki-67 and CD31, respectively. Bevacizumab alone did not inhibit OSCC cell proliferation in vitro, and did not exhibit any synergistic inhibitory effect in combination with $5-\mathrm{FU}$ in vitro. However, combined bevacizumab and S-1 therapy exerted synergistic and significant antitumor effects in vivo on HSC-2 tumor xenografts, and induced apoptosis in tumor cells. Furthermore, this combination therapy led to decreased MVD and cell proliferative abilities, as well as
\end{abstract}

Correspondence to: Dr Koji Harada, Department of Oral and Maxillofacial Surgery, Yamaguchi University Graduate School of Medicine, 1-1-1 Minamikogushi, Ube, Yamaguchi 755-8505, Japan E-mail: harako@yamaguchi-u.ac.jp

Key words: vascular endothelial growth factor-A, bevacizumab, $\mathrm{S}-1$, oral squamous cell carcinoma, combination therapy increased apoptosis in residual tumors. The present findings suggested that the bevacizumab plus S-1 combination therapy may exert antitumor effects in high VEGF-A-expressing OSCC cells.

\section{Introduction}

Recent advances in multidisciplinary treatments and reconstructive surgery have improved the overall survival (OS) of patients with oral cancer $(1,2)$. The worldwide incidence rate of oral cancer is 300,400 cases annually and the 5-year OS rate is $50-60 \%(1,2)$. Nevertheless, the complexities of the process of tumor progression and tumor recurrence in inoperable cases often cause huge obstacles in cancer treatment (3). Tegafur, a component of the oral antitumor drug S-1, is the prodrug of 5-fluorouracil (5-FU) that inhibits DNA synthesis and causes RNA dysfunction in cells, thereby exerting strong antitumor effects against solid cancers of the head and neck region (4-7). S-1 with tegafur/uracil exhibited significantly improved treatment outcome and improved the 3-year survival rate in patients with head and neck squamous cell carcinoma (HNSCC) who underwent curative treatment compared with the patients who did not have S1 treatment (8). Although S-1 is associated with side effects, including severe leukopenia, neutropenia, nausea, vomiting and diarrhea, the frequency and degree of side effects are lower than those reported for other chemotherapeutic agents, such as docetaxel, taxol and cisplatin (4-11).

Angiogenesis has been identified as an important determinant of solid tumor growth and metastasis. Several regulatory factors are involved in tumor angiogenesis, among which vascular endothelial growth factor (VEGF)-A serves a particularly important role (12-15). In a clinical trial of HNSCC, strong VEGF-A expression was negatively associated with OS and disease-free survival (16-19). Similarly, high VEGF-A expression was significantly associated with cancer progression and a poor prognosis (based on $\mathrm{T}$ classification, $\mathrm{N}$ classification, grade, clinical stage and cumulative survival) among patients with oral squamous cell carcinoma (OSCC) $(20,21)$. VEGF-A-targeting monoclonal antibody therapies have yielded successful results in various types of cancer including colorectal cancer and head and neck cancer (10-12,22-24 ). 
Bevacizumab is a molecularly targeted drug with different properties compared with conventional chemotherapeutic agents (25). It directly binds to VEGF-A around the tumor and inhibits tumor angiogenesis (12). Moreover, bevacizumab exerts an antitumor effect by inhibiting the nutrient supply to tumor cells (13). Additionally, bevacizumab normalizes residual blood vessels and improves the drug delivery system into the tumor so that drugs reach the tumor at a higher concentration $(10,11,22-24)$. In addition, the side effects of bevacizumab, which is administered by intravenous injection, differ from those of conventional chemotherapeutic agents (26,27). Common side effects of bevacizumab include bleeding, delayed wound healing, hypertension and proteinuria, which are rarely observed with conventional chemotherapy $(27,28)$. Therefore, bevacizumab can be used in combination with conventional antitumor drugs with low side effects $(10,11,22-24)$. A number of clinical trials with patients with recurrent and metastatic HNSCC and OSCC revealed that bevacizumab in combination with other molecular-targeted therapies, chemotherapies and/or radiation therapy led to improved OS and progression-free survival in numerous types of cancer, including HNSCC $(10,11,22-24,29)$. Previous studies reported that bevacizumab in combination with S-1 yielded modest to high efficacy against a number of types of cancer, such as advanced recurrent or metastatic colorectal cancer, advanced gastric cancer, advanced lung cancer, advanced esophageal carcinoma with mild and acceptable toxicities, especially as a second- or third-line therapy (12,23,30-33). However, to the best of our knowledge, there are no available reports on the efficacy of bevacizumab plus $\mathrm{S}-1$ treatment in HNSCC or OSCC.

In the present study, it was hypothesized that bevacizumab in combination with S-1 may exert stronger antitumor effect against OSCC cell lines compared with bevacizumab or S-1 alone. In addition, the possibility of fewer side effects of S-1 plus bevacizumab treatment in vivo compared with conventional chemotherapeutic agents was investigated.

\section{Materials and methods}

Cell lines, cell culture and reagents. The VEGF-A-expressing human oral or tongue cancer HSC-2, HSC-3, HSC-4 and SAS cell lines were obtained from the RIKEN BioResource Centre and maintained as monolayer cultures in DMEM/Ham's F12 with L-glutamine and phenol red medium (FUJIFILM Wako Pure Chemical Corporation) containing 10\% FBS (Thermo Fisher Scientific, Inc.), $100 \mu \mathrm{g} / \mathrm{ml}$ streptomycin and $100 \mathrm{U} / \mathrm{ml}$ penicillin (Thermo Fisher Scientific, Inc.) at $37^{\circ} \mathrm{C}$ in a humidified incubator with $5 \% \mathrm{CO}_{2}$.

FBS was not added to the cell culture medium subjected to western blotting, MTT assays and ELISA in order to avoid non-specific reactions with VEGF-A present in the FBS. S-1 was obtained from Taiho Pharmaceutical Co., Ltd., while bevacizumab was purchased from Chugai Pharmaceutical Co., Ltd.

Animals. A total of 12 female athymic BALB/c nu/nu nude mice (4-week-old) with an average body weight of $20 \mathrm{~g}$ were obtained from Japan SLC, Inc., and were kept under sterile conditions in a pathogen-free and temperature-controlled (average temperature, $22.1^{\circ} \mathrm{C}$ ) environment with a $12 \mathrm{~h}$ light/dark cycle. The mice received sterilized water and food ad libitum. All manipulations were conducted aseptically inside a laminar flow hood. All in vivo experiments were approved by the Institutional Animal Care and Use Committee of Yamaguchi University (Ube, Japan) (approval no. 55-010).

Western blotting. HSC-2, HSC-3, HSC-4 and SAS cell lines were grown to $80 \%$ confluency in a $100-\mathrm{mm}$ cell culture dish (BD Biosciences). After adding fresh FBS-free media, cells were incubated at $37^{\circ} \mathrm{C}$ for 24 and $48 \mathrm{~h}$. The cells were washed, collected by scraping and lysed in $100 \mathrm{ml}$ lysis buffer (1X formulation comprising $25 \mathrm{mM}$ Tris- $\mathrm{HCl} \mathrm{pH} 7.6$, $150 \mathrm{mM} \mathrm{NaCl}, 1 \% \mathrm{NP}-40,1 \%$ sodium deoxycholate and $0.1 \% \mathrm{SDS}$ ). Protein concentrations in the whole cell lysates were determined using NanoDrop ${ }^{\mathrm{TM}} 1000$ (Thermo Fisher Scientific, Inc.). A total of $80 \mu \mathrm{g}$ protein/lane was loaded into NuPAGE ${ }^{\mathrm{TM}} 4-12 \%$ Bis-Tris gel (cat.no. NP0322; Thermo Fisher Scientific, Inc.) and was subjected to SDS-PAGE and then transferred onto PVDF membranes. A blocking solution was made from Blocker/Diluent part A (cat. no. 46-7003; Thermo Fisher Scientific, Inc.) and B (cat. no. 46-7004; Thermo Fisher Scientific, Inc.) according to the manufacturer's protocol, and the PVDF membranes were incubated in the blocking solution at room temperature for $30 \mathrm{~min}$. Membranes were treated with VEGF-A (A-20 rabbit polyclonal; cat. no. SC-15;1:250; Santa Cruz Biotechnology, Inc.) (or $\alpha$-tubulin (loading control; B-7 mouse monoclonal; cat. no. SC-5286; 1:1,000; Santa Cruz Biotechnology, Inc.) primary antibody at $4^{\circ} \mathrm{C}$ overnight. The membranes were washed using $1 \mathrm{X}$ wash solution (cat. no. 46-7005; Thermo Fisher Scientific, Inc.) 3 times at room temperature ( $5 \mathrm{~min} / \mathrm{wash}$ ) according to manufacturer's instruction, and then was incubated with either secondary antibody solution Alk-Phos. conjugated anti-rabbit (cat. no. 46-7006; neat; Thermo Fisher Scientific, Inc.) or Alk-Phos. conjugated anti-mouse (cat. no. 46-7006; neat; Thermo Fisher Scientific Inc.) at room temperature for $30 \mathrm{~min}$. The membranes were washed 3 times with $1 \mathrm{X}$ wash solution at room temperature ( $5 \mathrm{~min} /$ wash) and protein bands were detected by incubating the membranes into Novex ${ }^{\circledR}$ AP Chromogenic substrate (BCIP/NBT) (cat. no. 100002902; Thermo Fisher Scientific, Inc.) at room temperature for 5-15 $\mathrm{min}$. Quantification of protein bands was performed using Image J v1.51h software (National Institutes of Health). The fold-change of VEGF-A expression was calculated relative to the control ( $\alpha$-tubulin) and expressed as a percentage.

MTT assay. SAS and HSC-2 cells were seeded into a 96-well plate (BD Biosciences) at a density of 5x103 cells/well and incubated at $37^{\circ} \mathrm{C}$ for $24 \mathrm{~h}$. Subsequently, cells were treated (at $37^{\circ} \mathrm{C}$ for 24 or $48 \mathrm{~h}$ ) as follows: Control (serum-free medium without drugs), bevacizumab alone $(1,10$ or $100 \mu \mathrm{g} / \mathrm{ml}$ ) or $5-\mathrm{FU}$ alone $(0.5,1$ or $2 \mu \mathrm{g} / \mathrm{ml})$ dissolved in serum-free medium. Cells were also treated with bevacizumab $(1,10$ or $100 \mu \mathrm{g} / \mathrm{ml})$ plus 5 -FU $(05,1$ or $2 \mu \mathrm{g} / \mathrm{ml})$ dissolved in serum-free medium at $37^{\circ} \mathrm{C}$ for $48 \mathrm{~h}$. Subsequently, MTT solution $(5 \mathrm{mg} / \mathrm{ml})$ was added to each well $(25 \mu \mathrm{l} /$ well $)$ and incubated for $4 \mathrm{~h}$ at $37^{\circ} \mathrm{C}$. The purple formazan was dissolved in dimethyl sulfoxide (100 $\mu \mathrm{l} /$ well) and the absorbance was measured using a spectrophotometer (Bio-Rad Laboratories, Inc.) at a wavelength of $490 \mathrm{~nm}$. All assays were performed in triplicate. 


\section{In vivo treatment protocol}

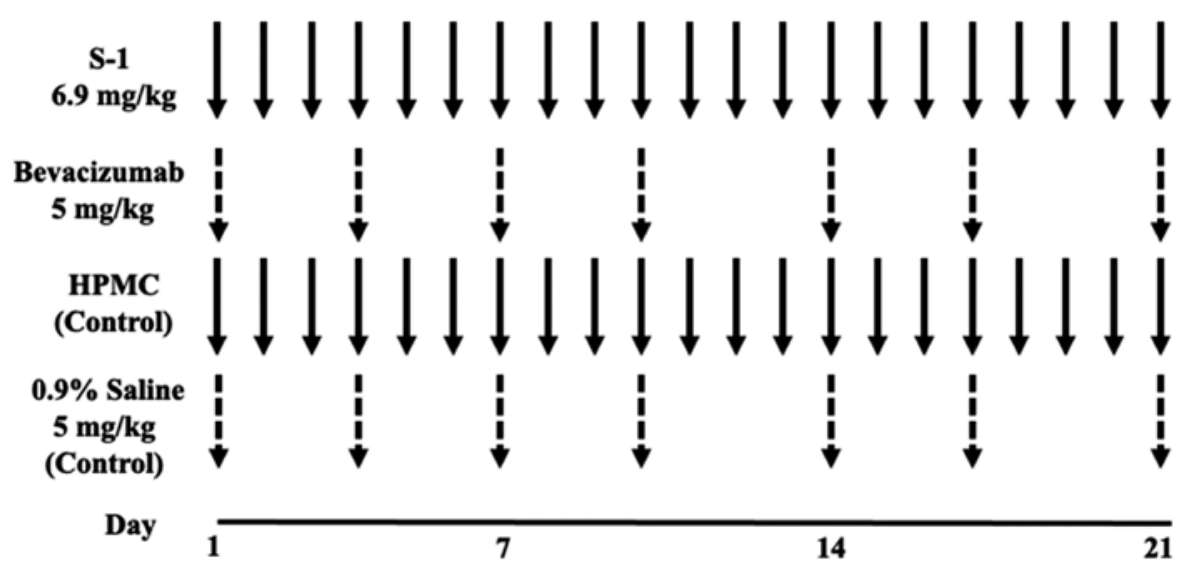

Figure 1. In vivo treatment protocol. A total of 1x10 ${ }^{6}$ HSC-2 cells were injected into the subcutaneous tissues of 5-week-old nude mice. After 10 days of tumor growth (volume, $\left.40-50 \mathrm{~mm}^{3}\right)$, the mice were divided into four groups $(\mathrm{n}=3)$. The $\mathrm{S}-1$ group received $\mathrm{S}-1 \mathrm{via}$ gastric lavage $(6.9 \mathrm{mg} / \mathrm{kg} / \mathrm{day})$ for 3 weeks, the bevacizumab group was injected with bevacizumab intraperitoneally (i.p; $5 \mathrm{mg} / \mathrm{kg}$ twice/week, on day 1 and 4 of each week) for 3 weeks, and the combination group received both S-1 (6.9 mg/kg/day) for 3 weeks and bevacizumab (5 mg/kg twice/week, on day 1 and 4 of each week) for 3 weeks. The control mice group received either $0.5 \%$ HPMC via gastric lavage or $0.9 \%$ saline $(5 \mathrm{ml} / \mathrm{kg}$ twice/week) for 3 weeks. HPMC, hydroxypropyl methylcellulose.

ELISA. SAS and HSC-2 cells were seeded into a 96-well plate (BD Biosciences) at a density of $5 \times 10^{3}$ cells/well, and wells were treated with one of the following treatments: Control (serum-free medium without drugs), bevacizumab alone $(10 \mu \mathrm{g} / \mathrm{ml}), 5-\mathrm{FU}$ alone $(1 \mu \mathrm{g} / \mathrm{ml})$ or bevacizumab $(10 \mu \mathrm{g} / \mathrm{ml})$ plus $5-\mathrm{FU}(1 \mu \mathrm{g} / \mathrm{ml})$. All cells were cultured at $37^{\circ} \mathrm{C}$ for 24 and $48 \mathrm{~h}$, then VEGF-A concentrations in the supernatant from each well were measured via ELISA Human VEGF Quantikine ELISA kit (cat. no. DVE00; R\&D Systems, Inc.) according to manufacturer's instructions.

Human cancer xenograft models. HSC-2 cells were used as a xenograft model in BALB/c nu/nu nude mice $(n=12)$ as they have relatively higher tumorigenic potential than SAS cells. HSC-2 cell line batches were frozen in FBS supplemented with $5 \%$ dimethyl sulfoxide (v/v) prior to injection into mice, and then were thawed shortly before injection. In brief, HSC-2 cells $\left(1 \times 10^{6} / \mathrm{mice}\right)$ were suspended into $0.1 \mathrm{ml}$ PBS $(0.05 \mathrm{M}$ phosphate buffer containing $0.145 \mathrm{M}$ sodium chloride, $\mathrm{pH} 7.4$ ) and injected into the subcutaneous tissues of aforementioned nude mice with a 27-gauge needle when they were 5-weeks old . Tumors were allowed to grow for 10 days before treatment. These tumor-bearing mice were divided into four groups $(n=3$; tumor volumes, $40-50 \mathrm{~mm}^{3}$ ). The humane endpoints of this in vivo experiment were: Rapid weight loss in treated mice ( $\geq 20 \%$ body weight loss compared with the control group), very large tumor (tumor weight $\geq 10 \%$ of body weight), skin/tumor ulceration or necrosis, difficulty in ambulation and feeding or drinking disorder.

In vivo treatment protocol. Fig. 1 shows the in vivo treatment protocol. The four treatment groups were: S-1, bevacizumab, combination therapy and control groups. S-1 was suspended in autoclaved $0.5 \%$ sodium hydroxypropyl methylcellulose (HPMC; Daiichi Kogyo Seiyaku Co., Ltd.) under sterile conditions to a concentration of $1.0 \mathrm{mg} / \mathrm{ml}$ and homogenized by stirring. The $\mathrm{S}-1$ suspension was administered to mice via gastric lavage at a dosage of $6.9 \mathrm{mg} / \mathrm{kg} /$ day for 3 weeks (S-1 group). Bevacizumab was injected intraperitoneally (i.p) at a dosage of $5 \mathrm{mg} / \mathrm{kg}$ twice/week (on day 1 and 4 of each week) for 3 weeks (bevacizumab group). The combination group received both $\mathrm{S}-1$ (6.9 $\mathrm{mg} / \mathrm{kg} /$ day for 21 days) and bevacizumab $5 \mathrm{mg} / \mathrm{kg}$ twice/week (on day 1 and 4 of each week) for 3 weeks. The control mice group received either 5\% HPMC (equal volume of S-1) via gastric lavage or $0.9 \%$ saline (i.p) at a dosage of $5 \mathrm{ml} / \mathrm{kg}$ twice/week for 3 weeks .

Tumor measurements. HSC-2 xenograft tumors were inspected twice/week and measured using a Vernier caliper. Tumor volume $\left(\mathrm{mm}^{3}\right)$ was calculated using the standard formula $a^{2} \times b / 2$, where ' $a$ ' is the width and ' $b$ ' the length of the horizontal tumor. Body weights were also measured every 2 days. On day 21, $12 \mathrm{~h}$ after the final drug dosage, the experiment was terminated based on ethical considerations, and the mice were sacrificed using an overdose of Somnopentyl (sodium pentobarbital, $200 \mathrm{mg} / \mathrm{kg}$; Merck \& Co., Inc.). The tumors were dissected, fixed in $10 \%$ neutral-buffered formalin at room temperature for $24 \mathrm{~h}$ (Mildform ${ }^{\circledR} 10 \mathrm{~N}$; FUJIFILM Wako Pure Chemical Corporation) and embedded in paraffin for further study. The relative tumor volume was calculated using the following formula: Tumor volume of the respective tumor on day $\mathrm{n} /$ volume of the same tumor on day 0 (before the treatment started).

Immunohistochemistry. Avidin-biotin complex-based immunohistochemical methods were performed to detect CD31 and Ki-67 in tissue specimens using the EnVision kit $^{\mathrm{TM}}$ (Dako; Agilent Technologies, Inc.). Paraffin-embedded tissue sections (4- $\mu$ m-thick) were deparaffinized in xylene and rehydrated through a descending alcohol series at room temperature. Deparaffinized sections were immersed in absolute methanol containing $0.3 \%$ hydrogen peroxide for $20 \mathrm{~min}$ at room temperature to block endogenous peroxidases. The sections were then treated with Dako REAL ${ }^{\mathrm{TM}}$ peroxidase-blocking solution (cat. no. S2023 Dako; Agilent Technologies, Inc.,) for $30 \mathrm{~min}$ at room temperature to block 
non-specific reactions and were incubated overnight at $4^{\circ} \mathrm{C}$ with goat anti-mouse CD31 or PECAM-1 (cat. no. SC-376764; 1:100; Santa Cruz Biotechnology, Inc.) and mouse anti-human Ki-67 (clone MIB-1; cat. no. M7240; 1:100; Dako; Agilent Technologies, Inc.). After rinsing the tissue sections in PBS thrice for $5 \mathrm{~min}$ each, $100 \mu \mathrm{l}$ secondary antibody (Dako REAL $^{\mathrm{TM}}$ Envision $^{\mathrm{TM}}$ detection system; horse radish peroxidase; rabbit/Mouse; cat. no. K5007; no dilution; Dako; Agilent Technologies, Inc.) was added at room temperature for $30 \mathrm{~min}$. Tissue sections were rinsed thrice in PBS for $5 \mathrm{~min}$ each, and incubated with an chromogen 3,3'-diaminobenzidine tetrahydrochloride (DAB) solution for $7 \mathrm{~min}$ at room temperature using Dako REAL ${ }^{\mathrm{TM}}$ Envision $^{\mathrm{TM}}$ detection system (cat. no. K5007; Dako; Agilent Technologies, Inc.). Tissue sections were then counterstained by hematoxylin at room temperature for $1 \mathrm{~min}$. Tissue sections were subsequently dehydrated in graded ethanol, cleared using Histo-Clear (cat. no. HS200; National Diagnostics) and mounted with glass coverslips using D.P.X. (Millipore Sigma). Each experiment included positive controls (for Ki-67: human tongue squamous cell carnimona tissue; for CD31: human healthy tongue tissues) and negative controls (same tissue samples without primary antibody).

Evaluation of microvessel density (MVD). Immunohistochemical techniques were used to evaluate MVD, and vascularity was determined as described previously $(34,35)$. Unlike immunohistochemical analysis, tumor vessels were stained with the aforementioned anti-mouse CD31 antibody for $90 \mathrm{~min}$ at room temperature. Paraffin sections were pre-treated with $0.01 \%$ protease at $37^{\circ} \mathrm{C}$ for $20 \mathrm{~min}$. The staining protocol was otherwise similar to that used for immunohistochemistry, as aforementioned. The number of vessels per field was counted in the area of highest vascular density. Vessel density was recorded as the number of $\mathrm{CD} 31^{+}$vessel points per field under x200 magnification using a fluorescence microscope (BX51; Olympus Corporation). Vascularity was quantified in the stroma close to the epithelium, up to $\sim 750 \mu \mathrm{m}$ from the basal lamina, and microvessels in the tumors were counted. A total of 10 randomly selected fields from non-necrotic tumor tissue were examined per section, and the results are expressed as the mean percentage \pm SD as previously described (36).

Evaluation of cell proliferation. Immunohistochemical techniques were also used to evaluate the cell proliferative ability. Tumor cells were stained with mouse anti-human Ki-67 by immunohistochemistry as aforementioned, and $\mathrm{Ki}-67^{+}$nuclei were counted under x200 magnification from a total of 1,000 cells to determine the distribution of cell proliferation using a fluorescence microscope (BX51; Olympus Corporation) as previously described (37).

Evaluation of apoptotic index. Tissue sections were subjected to TUNEL assay to examine apoptosis using the DeadEnd ${ }^{\mathrm{TM}}$ Fluorometric TUNEL system (cat. no. G3250; Promega, Corporation) according to manufacturer's instructions. Paraffin-embedded tumor sections (4- $\mu$ m-thick) were deparaffinized in xylene, rehydrated using a graded ethanol series and incubated with $20 \mu \mathrm{g} / \mathrm{ml}$ proteinase K (Dako; Agilent Technologies, Inc.) at room temperature for $15 \mathrm{~min}$. The sections were then rinsed with distilled water and incubated in a
$3 \%$ hydrogen peroxide solution at room temperature for $5 \mathrm{~min}$ to block endogenous peroxidases. The sections were then washed with PBS, incubated in an equilibration buffer and treated with TdT enzyme in a humidified chamber at $37^{\circ} \mathrm{C}$ for $60 \mathrm{~min}$. Slides were subsequently placed in working strength stop wash buffer at room temperature for $10 \mathrm{~min}$, rinsed with PBS and incubated with an anti-digoxigenin-peroxidase conjugate at room temperature for $30 \mathrm{~min}$. Diaminobenzidine (Peroxidase Substrate kit; Vector Laboratories, Inc.) was then applied to each section to reveal peroxidase activity. Hematoxylin was used at room temperature for $1 \mathrm{~min}$ as the counterstain. TUNEL-positive cells were counted under x200 magnification from a minimum of 5 microscopic fields per section using a fluorescence microscope (BX51; Olympus Corporation) to determine the distribution of apoptotic cells. The apoptotic index was reported as the percentage of TUNEL-positive cells per 1,000 total cells as previously described (38).

Statistical analysis. MTT and ELISA data of drug-treated cells, tumor measurements, MVD, cell proliferative ability and apoptotic index were compared using one-way ANOVA followed by the post hoc Tukey's test. All data were presented as the mean \pm SD. The Statcels ${ }^{\circledR}{ }^{\circledR}$ 4-Step Excel Statistics software application was used for the analyses (OMS Publishing, Inc.; https://oms-publ.memo.jp/main/). $\mathrm{P}<0.05$ was considered to indicate a statistically significant difference.

\section{Results}

Endogenous VEGF-A expression in four OSCC cell lines in vitro. Western blotting of the cultured cell lines revealed the highest levels of VEGF-A expression in HSC-2 cells after 24 and 48 h of culture, followed by HSC-3, HSC-4 and SAS cells (Fig. 2).

Inhibitory effects of 5-FU and bevacizumab on SAS and $H S C-2$ cell proliferation in vitro. No significant decrease in SAS and HSC-2 cell proliferation was observed after treatment with 5-FU alone or bevacizumab alone for $24 \mathrm{~h}$ compared with no treatment (Fig. 3). Treatment with 5-FU alone for $48 \mathrm{~h}$ significantly inhibited the proliferation of SAS and HSC-2 cells compared with no treatment; however, bevacizumab treatment alone for $48 \mathrm{~h}$ did not exert any effect (Fig. 3). Although combined treatment with 5-FU and bevacizumab significantly inhibited the proliferation of both SAS and HSC-2 cells, no synergistic or additive effects were observed (Fig. 4).

Effects of 5-FU and bevacizumab on VEGF-A production by SAS and HSC-2 cells in vitro. Treatment with 5-FU alone significantly decreased VEGF-A production in both SAS and HSC-2 cells compared with the control, and further decreases were observed with bevacizumab alone and in combination with 5-FU after 24 and $48 \mathrm{~h}$ of treatment (Fig. 5). In both cell lines, significant differences were observed after 24 and $48 \mathrm{~h}$ of treatment with either agent, alone or in combination, compared with the control (Fig. 5).

Relative changes in tumor volume over time. On average, tumor growth inhibition was observed with bevacizumab alone, S-1 alone or both agents in combination, and this inhibition 


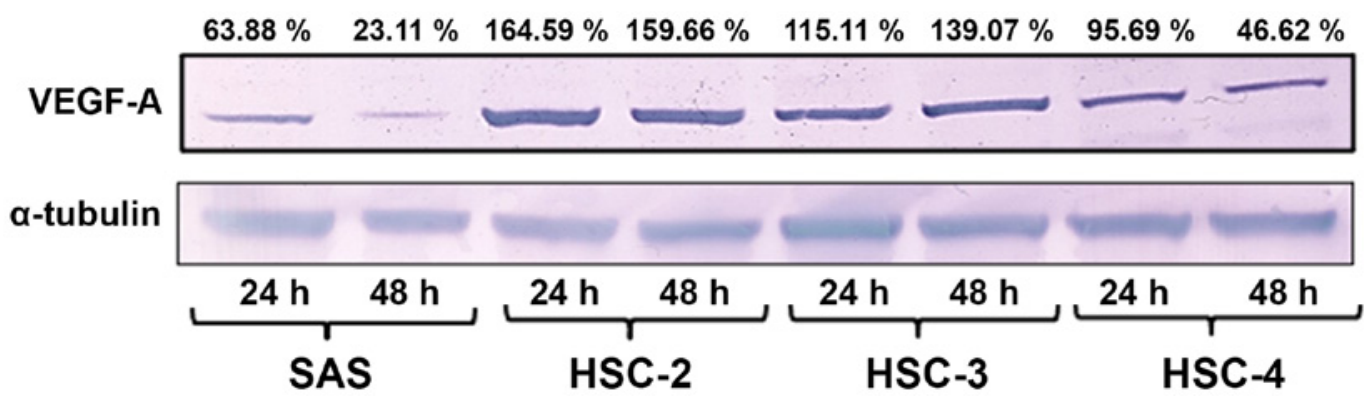

Figure 2. Endogenous VEGF-A expression in four OSCC cell lines in vitro. The OSCC SAS, HSC-2, HSC-3 and HSC-4 cell lines were incubated at $37^{\circ} \mathrm{C}$ for 24 or $48 \mathrm{~h}$ in FBS-free media. The highest VEGF-A expression was observed in HSC-2 cells, followed by HSC-3, HSC-4 and SAS at both time points. The fold-change of VEGF-A expression was calculated relative to the control ( $\alpha$-tubulin) and expressed as a percentage. OSCC, oral squamous cell carcinoma; VEGF-A, vascular endothelial growth factor A.
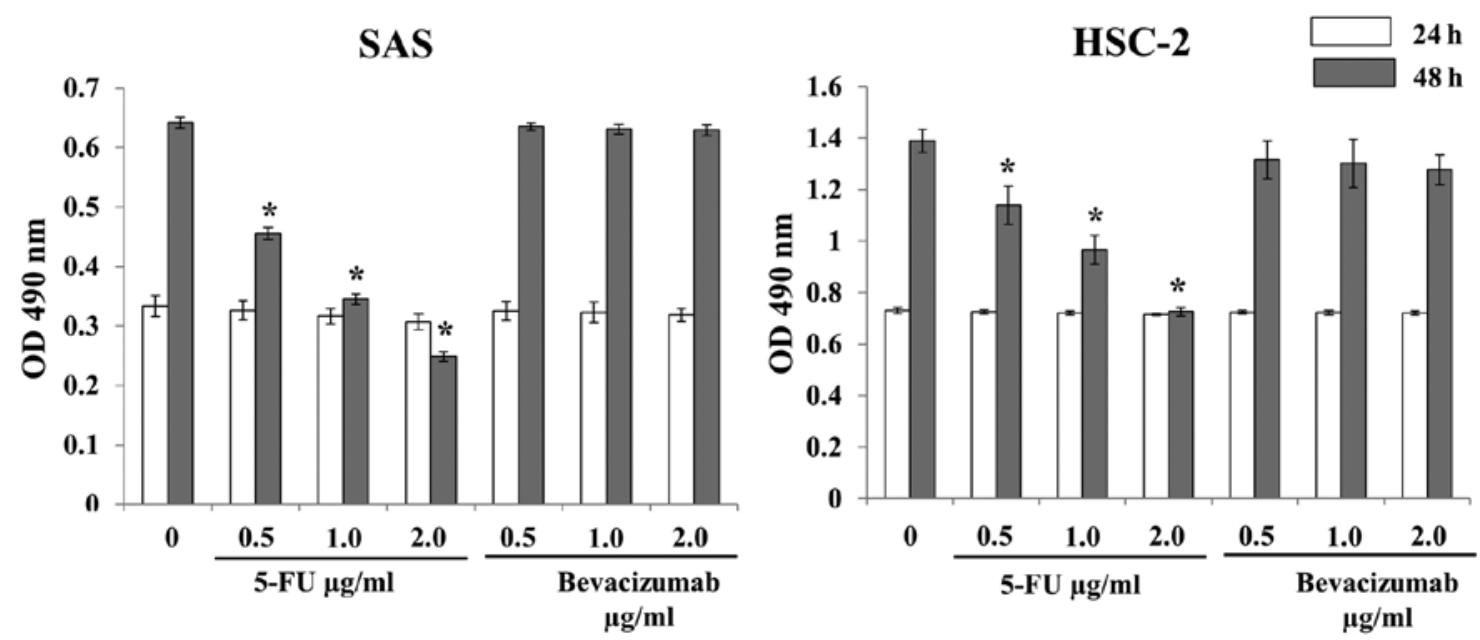

Figure 3. Inhibitory effects of 5-FU alone and bevacizumab alone on SAS and HSC-2 cell proliferation in vitro. 5-FU or bevacizumab alone did not inhibit cell proliferation in either cell line when treated for $24 \mathrm{~h}$. For both cell lines, treatment with 5-FU alone for $48 \mathrm{~h}$ inhibited cell proliferation in a dose-dependent manner, and there was a significant difference between the control and treated cells. However, bevacizumab treatment alone did not have a similar effect. The data are presented as the mean $\pm \mathrm{SD}$. ${ }^{\mathrm{P}} \mathrm{P}<0.05$ vs. respective control (one-way ANOVA). OD, optical density; 5-FU, 5-fluorouracil.

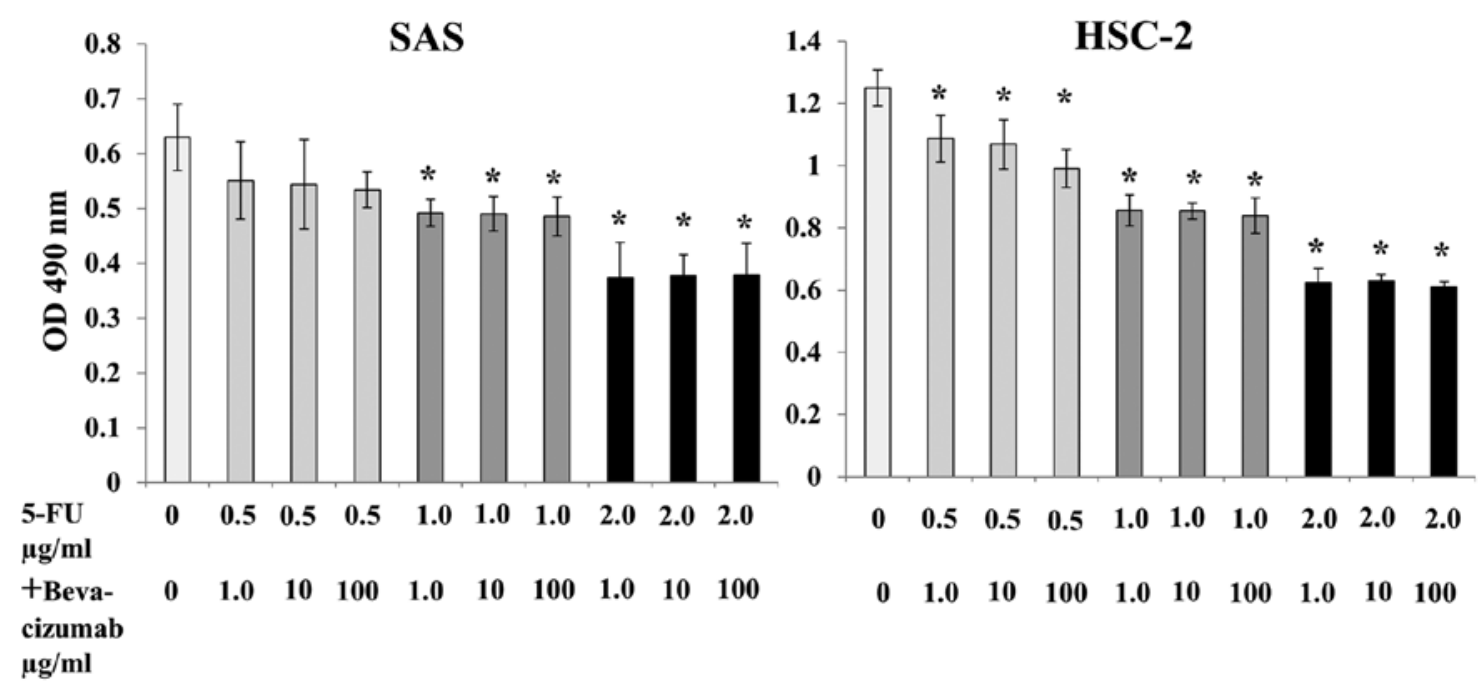

Figure 4. Inhibitory effects of 5-FU plus bevacizumab on SAS and HSC-2 cell proliferation in vitro. Compared with the control, combined treatment inhibited the proliferation of both SAS and HSC-2 cells. No synergistic or additive effects were observed. The data are presented as the mean \pm SD. ${ }^{*} \mathrm{P}<0.05$ vs. control (one-way ANOVA). OD, optical density; 5-FU, 5-fluorouracil.

was significantly different compared with that in the control group (Fig. 6). Bevacizumab was more effective than S-1 at decreasing tumor volume, and the combination of bevacizumab and S-1 was significantly more effective than either agent 

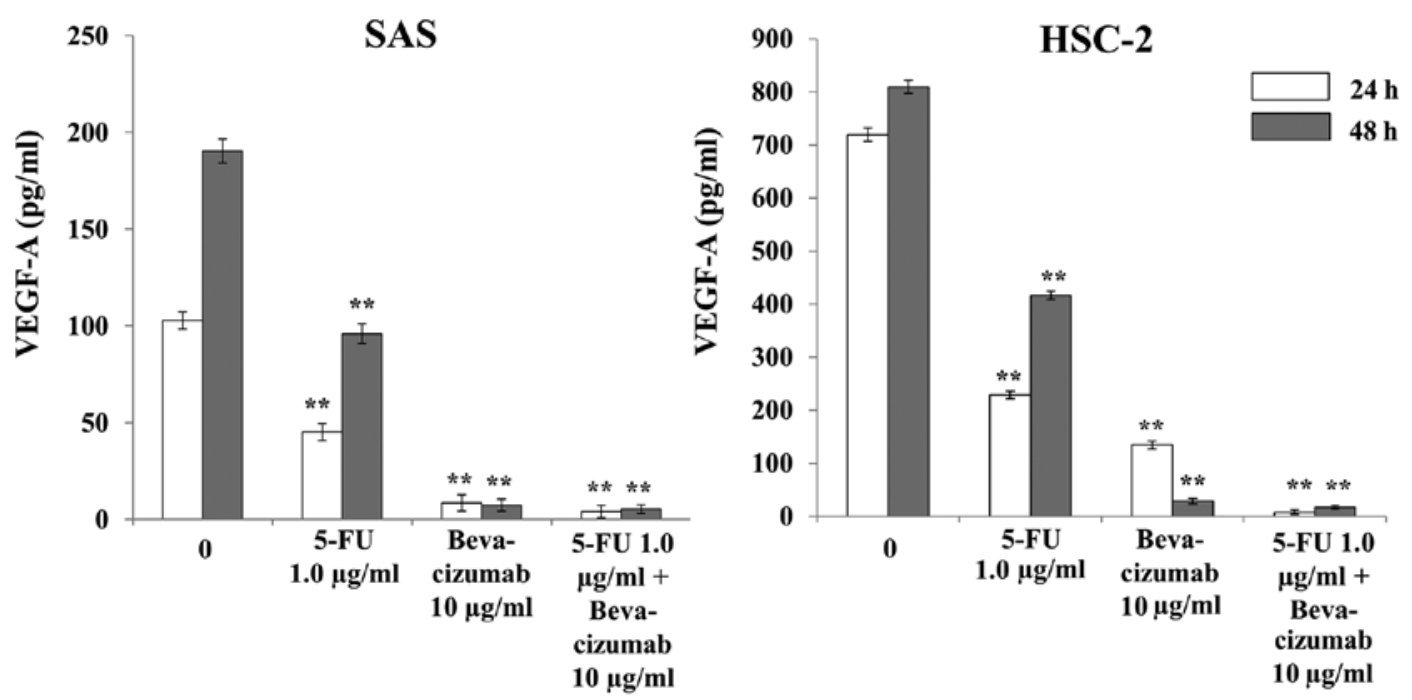

Figure 5. Effects of 5-FU and bevacizumab on VEGF-A production by SAS and HSC-2 cells in vitro via ELISA. The amount of VEGF-A produced by both SAS and HSC-2 cells treated with 5-FU and bevacizumab alone or in combination differed significantly from the control. The data are presented as the mean $\pm \mathrm{SD}$. ${ }^{* *} \mathrm{P}<0.01$ vs. respective control (one-way ANOVA). F-FU, 5 -fluorouracil; VEGF-A, vascular endothelial growth factor A.

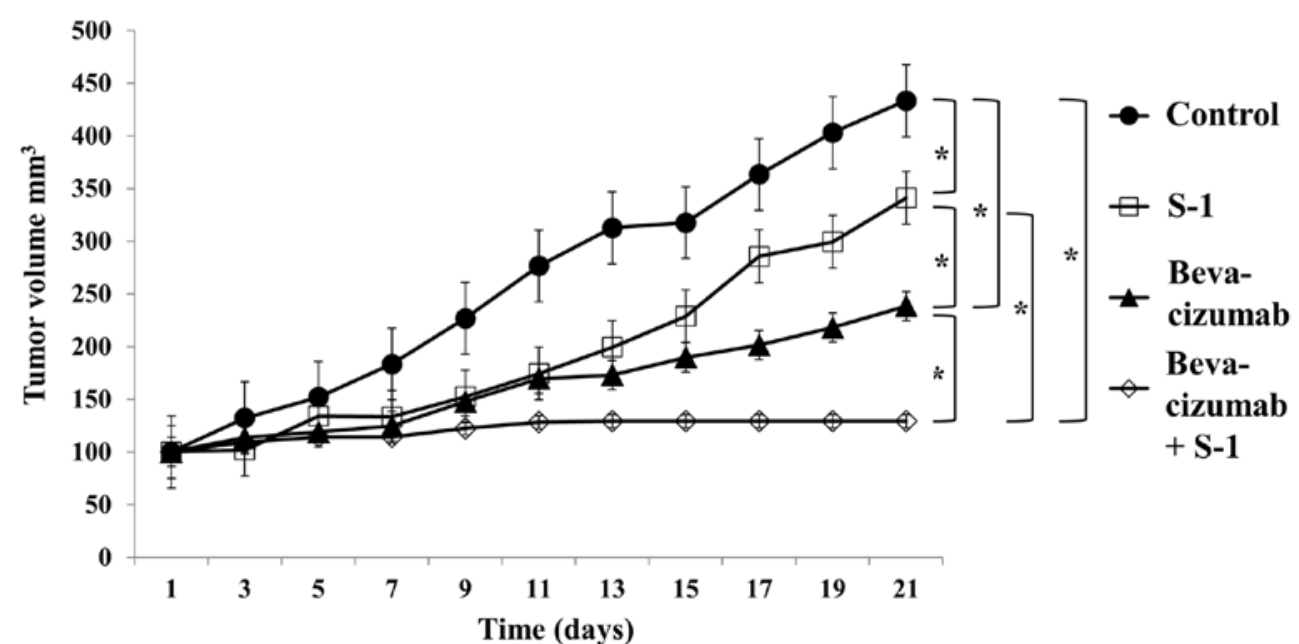

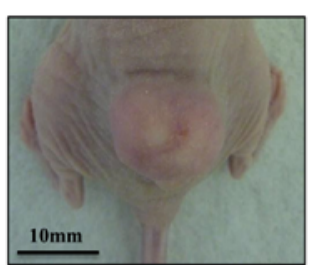

Control

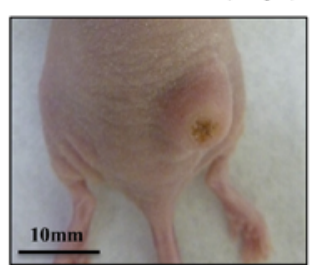

S-1

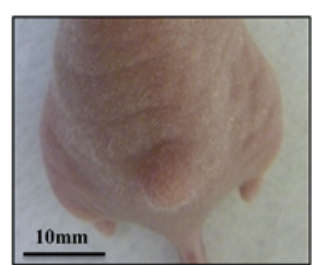

Bevacizumab

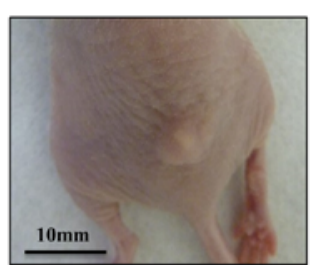

Bevacizumab + S-1

Figure 6. Inhibitory effects of S-1 and bevacizumab on tumor growth in vivo. The effects of bevacizumab alone, S-1 alone and combined therapy on HSC-2 tumor growth were observed in nude mice during a 21-day period of in vivo experiment. Bevacizumab, either alone or in combination with S-1, yielded significant growth inhibition compared with the control and S-1 alone. Combination treatment significantly decreased the tumor size compared with bevacizumab alone. No increase in tumor volume was observed in the group receiving combined therapy after day 13 . Scale bar, $10 \mathrm{~mm}$. The data are presented as the mean $\pm \mathrm{SD}$. ${ }^{*} \mathrm{P}<0.05$ (one-way ANOVA).

alone (Fig. 6). No increase in tumor volume was observed in mice treated with the combination of bevacizumab and S-1 after day 13 (Fig. 6). No loss of body weight was observed in any treated mice during the experimental period (data not shown). Furthermore, no abnormalities were observed in the heart, lung, liver and kidney of mice by the naked eye (data not shown).

Effects of $S$ - 1 and bevacizumab on residual tumor MVD in vivo. Mice tumor sections were subjected to immunohistochemical staining with CD31 to clarify the antitumor mechanisms affecting MVD. The following MVD values were recorded for each group: Control group, $215.67 \pm 30.55 \%$; bevacizumab group, $98.00 \pm 11.79 \%$; S-1 group, $114.33 \pm 12.66 \%$; and combination group, $75.33 \pm 7.57 \%$ (Fig. 7). The MVDs of the S-1 alone, bevacizumab alone and combination groups were significantly lower than that of the control group (Fig. 7). Although the MVD value of bevacizumab alone was lower than that of S-1 alone, and the MVD of the combination group was lower than 


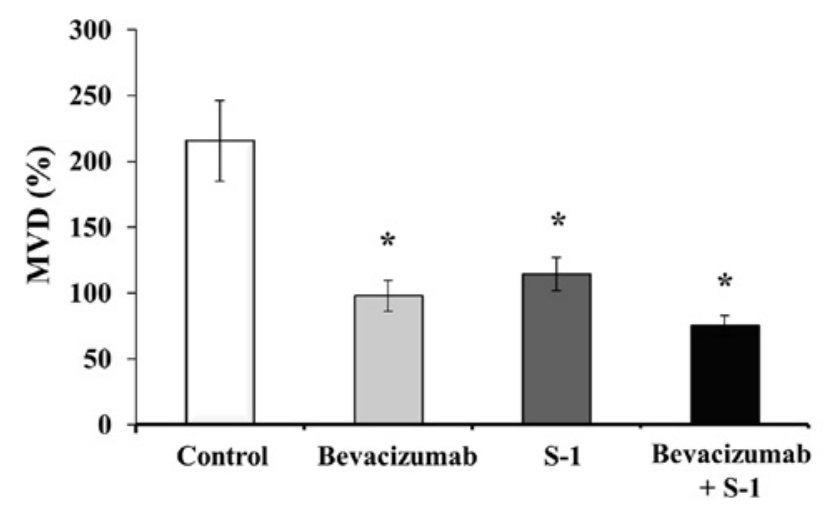

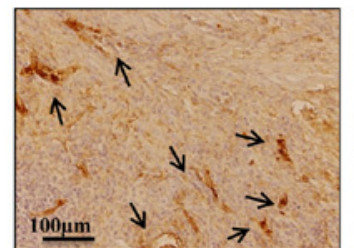

Control

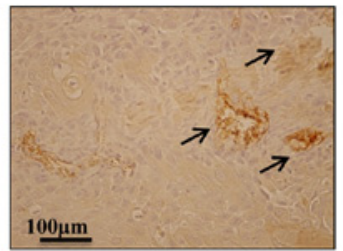

Bevacizumab

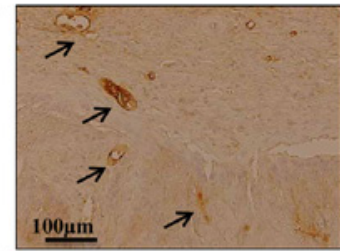

S-1

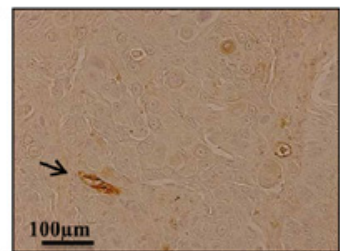

Bevacizumab + S-1

Figure 7. Effects of S-1 and bevacizumab on residual tumor MVD in vivo. Bevacizumab alone, S-1 alone and combination therapy all significantly decreased the tumor MVD in vivo compared with the control. Scale bar, $100 \mu \mathrm{m}$. The data are presented as the mean \pm SD. * $<<0.05$ vs. control (one-way ANOVA). MVD, microvessel density.

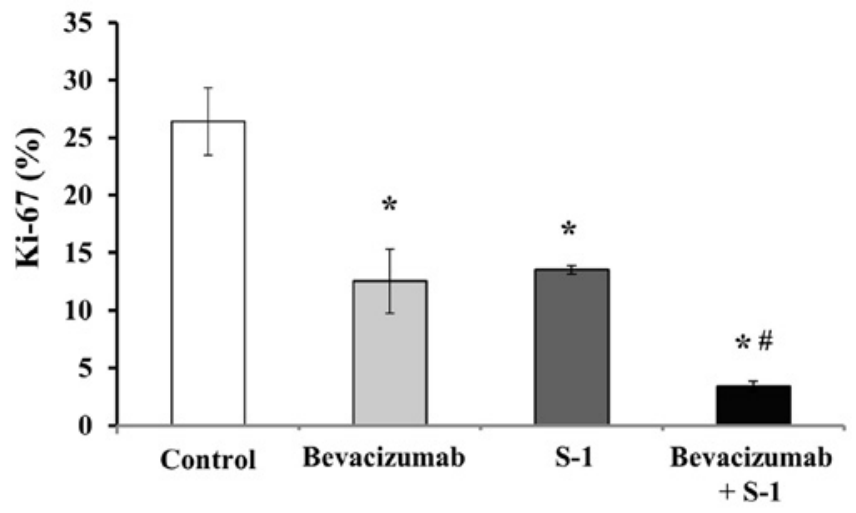

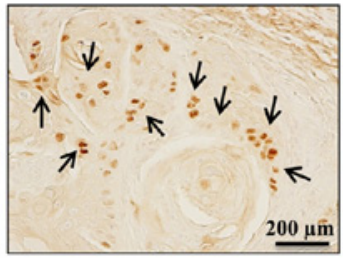

Control

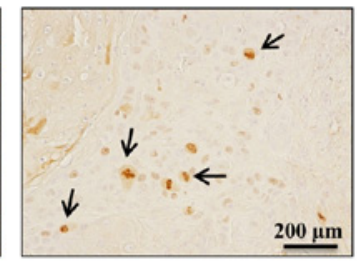

Bevacizumab

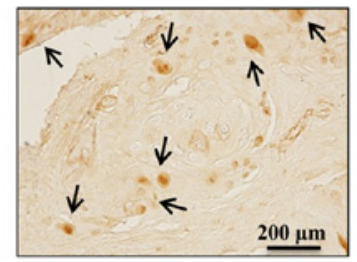

S-1

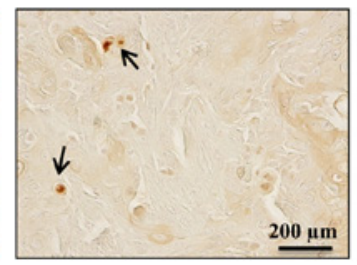

Bevacizumab + S-1

Figure 8. Inhibitory effects of S-1 and bevacizumab on cell proliferation in vivo. Bevacizumab alone, S-1 alone and bevacizumab plus S-1 all significantly decreased the cell proliferation in vivo compared with the control. Scale bar, $200 \mu \mathrm{m}$. The data are presented as the mean $\pm \mathrm{SD}$. ${ }^{\mathrm{P}<0.05}$ vs. control; ${ }^{\#} \mathrm{P}<0.05$ vs. Bevacizumab or S-1 (one-way ANOVA).

bevacizumab or S-1 alone, no significant differences were observed among the treatment groups (Fig. 7).

Inhibitory effects of $S-1$ and bevacizumab on cell proliferation in vivo. Tumor sections were stained with Ki-67 via immunohistochemistry, and the numbers of Ki- $67^{+}$nuclei were quantified to analyze the degree of inhibition of cell proliferation. Tumors treated with either bevacizumab or S-1 alone exhibited significantly decreased cell proliferative abilities compared with the control group (Fig. 8). Additionally, the number of $\mathrm{Ki}-67^{+}$nuclei was significantly lower in tumors treated with both bevacizumab and S-1 compared with that of tumors in the control or individual treatment groups (Fig. 8). The number of $\mathrm{Ki}-67^{+}$nuclei in different treatment groups was: Control group, 26.40 $2.91 \%$; bevacizumab group, $12.53 \pm 2.80 \%$; S-1 group, $13.53 \pm 0.38 \%$; combination group, $3.40 \pm 0.46 \%$ (Fig. 8).

Effects of $S-1$ and bevacizumab on apoptosis induction in vivo. Next, the rate of apoptosis in nude mice tumors was 


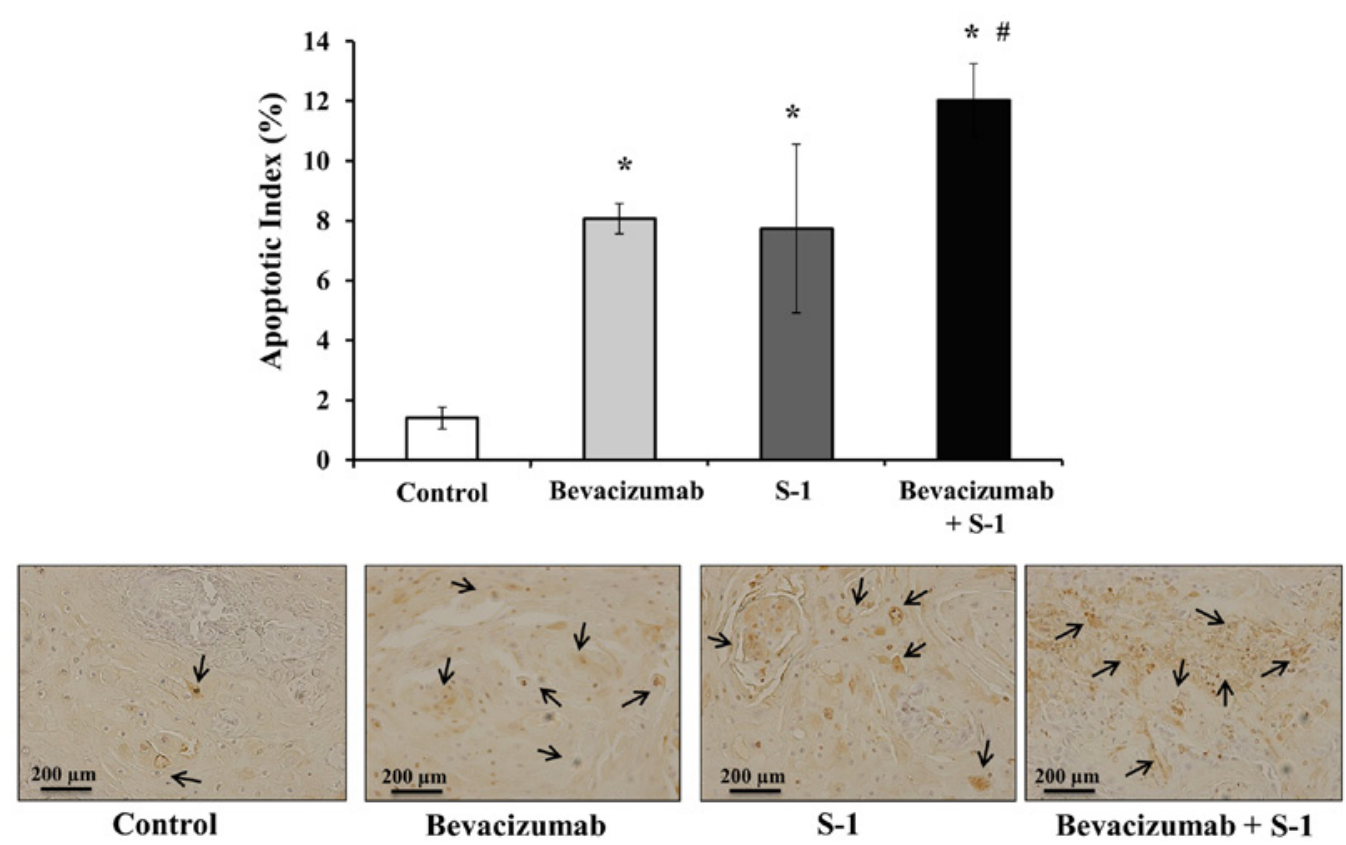

Figure 9. Effects of S-1 and bevacizumab on apoptosis induction in vivo. Treatment with bevacizumab alone, S-1 alone and bevacizumab plus S-1 led to a significantly higher apoptotic index in vivo compared with the control, as assessed by TUNEL assay. Scale bar, $200 \mu \mathrm{m}$. The data are presented as the mean \pm SD "P $<0.05$ vs. control; ${ }^{*} \mathrm{P}<0.05$ vs. S-1 or bevacizumab (one-way ANOVA).

analyzed after treatment with bevacizumab or S-1, alone or in combination. The number of apoptotic cells in each harvested tumor was quantified using a TUNEL assay. A significantly higher degree of apoptosis was observed in tumors treated with either bevacizumab or S-1 alone compared with the control group (Fig. 9). However, the highest number of apoptotic cells was observed in tumors treated with bevacizumab and S-1 in combination; this combination treatment significantly induced apoptosis compared with each agent alone, as well as compared with the control (Fig. 9). The apoptotic indexes were as follows: Control group, $1.4 \pm 0.36 \%$; bevacizumab group, $8.07 \pm 0.5 \%$; S-1 group, $7.73 \pm 2.82 \%$; and combination group, $12.0 \pm 1.22 \%$ (Fig. 9).

\section{Discussion}

A number of mice xenografts studies have revealed that 5-FU metabolized from S-1 exerts significant antitumor effects and inhibits tumor angiogenesis by inducing apoptosis of the tumor vascular endothelial cells in various types of tumor, including human OSCC (6-8,38-40). Additionally, bevacizumab monotherapy exhibited antitumor effects in nude mice with OSCC and HNSCC tumors (12). Moreover, this antitumor effect of bevacizumab was enhanced when administered in combination with paclitaxel, irinotecan, cisplatin, interleukin-8, irradiation or cetuximab (36,41-44).

In the present study, a synergistic and suppressive antitumor effect of bevacizumab plus S-1 combination therapy was observed against OSCC in vivo. Although the combined treatment with 5-FU and bevacizumab inhibited the proliferation of SAS and HSC-2 cells in vitro, it did not exhibit any synergistic effect. On the other hand, the results of the current in vivo experiments suggested that the anti-angiogenic action of bevacizumab and the antitumor effect of S-1 synergistically inhibited tumor cell proliferation and promoted apoptosis.
Although VEGF-A expression was not analyzed in mice tumors, it may be possible that $\mathrm{S}-1 / 5-\mathrm{FU}$ downregulated VEGF expression by suppressing $\mathrm{NF}-\kappa \mathrm{B}$, which finally resulted in decreased MVD and inhibited angiogenesis $(8,45)$.

Similar results were obtained in two types of OSCC cell lines in vitro: HSC-2, which expressed high levels of VEGF-A, and SAS, which expressed low levels of VEGF-A; however, there was no synergistic effect of the combination treatment. HSC-2 cells are derived from squamous cell carcinoma of the mouth; it has an epithelial cell-like morphology and no metastatic potential (46). On the other hand, SAS is a poorly differentiated squamous cell carcinoma cell line from a human tongue primary lesion (47). 5-FU inhibited cell proliferation and directly decreased VEGF-A expression. By contrast, bevacizumab alone did not inhibit cell proliferation and did not exhibit a synergistic suppressive effect when administered in combination with 5-FU; in other words, it did not have a direct antitumor effect in vitro. However, bevacizumab neutralized VEGF-A expression in the culture supernatant, thus decreasing the concentration of VEGF-A around the neoplastic cells. The reason why bevacizumab alone did not exert antitumor effect or apoptosis in vitro remains unknown and should be further clarified in the future.

Based on the present results, it can be assumed that bevacizumab alone cannot exert antitumor effects in an in vitro environment (48). However, it can possibly exert antitumor effects in an in vivo environment, which is a complex mixture of tumor cells, tumor blood vessels and interstitial cells. In the present study, HSC-2 cells were used for the in vivo experiments, as this cell line had a higher tumorigenic potential and it strongly expressed VEGF-A compared with the SAS cell line.

It has been reported that 5-FU inhibits tumor cell proliferation and has an anti-angiogenic effect, which is not as strong as bevacizumab $(32,33,36,38,40,41)$. In the present study, it was observed that in the S-1 alone group, 5-FU metabolized from 
S-1 exerted an antitumor effect by inhibiting cell proliferation and inducing apoptosis in vivo, as well as by decreasing MVD. However, we assumed that bevacizumab alone led to the regression of immature tumor blood vessels and a negative feedback loop involving continuous reduction of the nutrient supply to cancer cells; these factors ultimately led to the inhibition of cell proliferation and induction of apoptosis.

Tumor progression was slowed down by S-1 or bevacizumab alone, but was not completely inhibited in mice. It can be hypothesized that, in the combination group, the marked decreases in tumor progression, MVD and cell proliferative ability, and the increase in the apoptotic index may be attributed to an improved ability to maintain homeostasis, which was absent in the S-1 or bevacizumab alone groups. Hence, we suggest the following mechanism behind the antitumor effect of S-1 and bevacizumab combination therapy. Bevacizumab binds to VEGF-A secreted from tumor cells and may induce the regression of immature tumor blood vessels and a negative feedback cycle that disrupts the continuous nutrient supply to cancer cells, thus inhibiting cell proliferation and promoting apoptosis. At the same time, it may be assumed that S-1 exerts direct antitumor effects, as well as promoting continuous indirect antitumor angiogenesis inhibition, thereby exerting marked antitumor effects. This may be a reason for the marked antitumor effect of the combination treatment on cell proliferation and apoptosis, but not for the direct effect on angiogenesis. However, the underlying mechanisms of $\mathrm{S}-1$ and bevacizumab combination treatment in OSCC are not completely understood, and there may be other unknown underlying factors responsible for the efficacy of this combination treatment. Additionally, the present study did not analyze VEGF-A expression in mice tumors nor the concentrations of drugs within tumor tissues, adjacent tissues or plasma. Therefore, this should be further investigated in future studies.

Recent findings have indicated that once a solid tumor reaches a certain size, it begins to secrete various angiogenic factors to promote the neovasculature $(49,50)$. Tumor growth can be suppressed by blocking blood vessels that feed tumors, which can then disappear via tumor dormancy without metastasis $(51,52)$. Given the lack of further increase in tumor volume after day 13 of the bevacizumab and S-1 combination therapy in the present study, the potential need for tumor dormancy therapy in OSCC should be considered, as proposed by Folkman and Hochberg (53). In other words, bevacizumab inhibits VEGF-A secretion from tumor cells and causes simultaneous inhibition of tumor growth and angiogenesis. Bevacizumab exerts a significant antitumor effect by improving drug delivery and thus allowing high concentrations of 5-FU to diffuse into the tumor (54). Therefore, conventional chemotherapy can directly exert antitumor effect on tumor cells, whereas bevacizumab can indirectly inhibit cell proliferation and increase apoptosis by decreasing nutrition supply to the tumor (55). In addition, bevacizumab can be expected to have further antitumor effects if combined with conventional antitumor agents (56). Hence, the current combination therapy may be used as a new treatment for OSCC due to its enhanced antitumor effects.

In conclusion, the combined treatment of S-1 and bevacizumab was effective against OSCC cells in vitro and exhibited marked synergistic antitumor effects in vivo. This combination therapy seemed to inhibit cell proliferation and promote apoptosis by controlling tumor angiogenesis. The present results indicated that $\mathrm{S}-1$ and bevacizumab combination therapy may be a useful and promising treatment for refractory, highly angiogenic OSCC tumors.

\section{Acknowledgements}

Not applicable.

\section{Funding}

The present study was supported in part by Grant-in-Aid from the Japanese Ministry of Education, Science and Culture (grant nos. 21890168 and 15K11292).

\section{Availability of data and materials}

The datasets used and/or analyzed during the current study are available from the corresponding author on reasonable request.

\section{Authors' contributions}

YI and KH designed the study. YI and TT performed the experiments. YI, TF and KH analyzed the data, wrote and revised the manuscript. YI, TF and KH confirmed the authenticity of all the raw data. YU and KM helped in analysis and interpretation of data, revised the manuscript and provided valuable suggestions during the study. All authors have read and approved the final version of the manuscript and are fully responsible for its content.

\section{Ethics approval and consent to participate}

All in vivo experiments were approved by the Institutional Animal Care and Use Committee of Yamaguchi University (approval no. 55-010; Ube, Japan).

\section{Patient consent for publication}

Not applicable.

\section{Competing interests}

The authors declare that they have no competing interests.

\section{References}

1. Joo YH, Cho JK, Koo BS, Kwon M, Kwon SK, Kwon SY Kim MS, Kim JK, Kim H, Nam I, et al: Guidelines for the surgical management of oral cancer: Korean society of thyroid-head and neck surgery. Clin Exp Otorhinolaryngol 12: 107-144, 2019.

2. Chi AC, Day TA and Neville BW: Oral cavity and oropharyngeal squamous cell carcinoma - an update. CA Cancer J Clin 65: 401-421, 2015.

3. Vermorken JB, Remenar E, van Herpen C, Gorlia T, Mesia R, Degardin M, Stewart JS, Jelic S, Betka J, Preiss JH, et al; EORTC 24971/TAX 323 Study Group: Cisplatin, fluorouracil, and docetaxel in unresectable head and neck cancer. N Engl J Med 357: 1695-1704, 2007.

4. Tsukuda M, Kida A, Fujii M, Kono N, Yoshihara T, Hasegawa Y and Sugita M; Chemotherapy Study Group of Head and Neck Cancer: Randomized scheduling feasibility study of S-1 for adjuvant chemotherapy in advanced head and neck cancer. Br J Cancer 93: 884-889, 2005. 
5. Harada K, Sato M, Ueyama Y, Nagayama M, Hamakawa H, Nagahata S, Yoshimura Y, Osaki T and Ryoke K; Oral Cancer Study Group of Chugoku-Shikoku: Multi-institutional phase II trial of S-1 in patients with oral squamous cell carcinoma. Anticancer Drugs 19: 85-90, 2008.

6. Yokoe H, Kasamatsu A, Ogawara K, Ishigami T, Sato Y, Shibata M, Tanzawa H and Uzawa K: Neoadjuvant chemotherapy with S-1 for patients with oral squamous cell carcinoma. J Cancer Sci Ther 2: 132-135, 2010.

7. Tsukahara K, Kubota A, Hasegawa Y, Takemura H, Terada T, Taguchi T, Nagahara K, Nakatani H, Yoshino K, Higaki Y, et al Randomized phase III trial of adjuvant chemotherapy with S-1 after curative treatment in patients with squamous-cell carcinoma of the head and neck (ACTH-HNC). PLoS One 11: 1-15, 2015.

8. Harada K, Ferdous T and Ueyama Y: Therapeutic strategies with oral fluoropyrimidine anticancer agent, S-1 against oral cancer. Jpn Dent Sci Rev 53: 61-77, 2017.

9. Sakuramoto S, Sasako M, Yamaguchi T, Kinoshita T, Fujii M, Nashimoto A, Furukawa H, Nakajima T, Ohashi Y, Imamura $\mathrm{H}$, et al; ACTS-GC Group: Adjuvant chemotherapy for gastric cancer with S-1, an oral fluoropyrimidine. N Engl J Med 357: 1810-1820, 2007.

10. Yamada Y, Takahari D, Matsumoto H, Baba H, Nakamura M, Yoshida K, Yoshida M, Iwamoto S, Shimada K, Komatsu Y, et al: Leucovorin, fluorouracil, and oxaliplatin plus bevacizumab versus S-1 and oxaliplatin plus bevacizumab in patients with metastatic colorectal cancer (SOFT): An open-label, non-inferiority, randomised phase 3 trial. Lancet Oncol 14: 1278-1286, 2013.

11. Presta LG, Chen H, O'Connor SJ, Chisholm V, Meng YG, Krummen L, Winkler M and Ferrara N: Humanization of an anti-vascular endothelial growth factor monoclonal antibody for the therapy of solid tumors and other disorders. Cancer Res 57: 4593-4599, 1997.

12. Yoshida H, Yoshimura H, Matsuda S, Ryoke T, Kiyoshima T, Kobayashi M and Sano K: Effects of peritumoral bevacizumab injection against oral squamous cell carcinoma in a nude mouse xenograft model: A preliminary study. Oncol Lett 15: 8627-8634, 2018.

13. Willett CG, Boucher Y, di Tomaso E, Duda DG, Munn LL, Tong RT, Chung DC, Sahani DV, Kalva SP, Kozin SV, et al: Direct evidence that the VEGF-specific antibody bevacizumab has antivascular effects in human rectal cancer. Nat Med 10 : 145-147, 2004

14. Tong M, Lloyd B, Pei P and Mallery RS: Human head and neck squamous cell carcinoma cells are both targets and effectors for the angiogenic cytokine, VEGF. J Cell Biochem 105: 1202-1210 2008 .

15. Vassilakopoulou M, Psyrri A and Argiris A: Targeting angiogenesis in head and neck cancer. Oral Oncol 51: 409-415, 2015.

16. Mineta H, Miura K, Ogino T, Takebayashi S, Misawa K, Ueda Y, Suzuki I, Dictor M, Borg A and Wennerberg J: Prognostic value of vascular endothelial growth factor (VEGF) in head and neck squamous cell carcinomas. Br J Cancer 83: 775-781, 2000.

17. Smith BD, Smith GL, Carter D, Sasaki CT and Haffty BG: Prognostic significance of vascular endothelial growth factor protein levels in oral and oropharyngeal squamous cell carcinoma. J Clin Oncol 18: 2046-2052, 2000

18. Tse GM, Chan AW, Yu KH, King AD, Wong KT, Chen GG, Tsang RK and Chan AB: Strong immunohistochemical expression of vascular endothelial growth factor predicts overall survival in head and neck squamous cell carcinoma. Ann Surg Oncol 14: $3558-3565,2007$

19. O-charoenrat: P, Rpys-Evans P and Eccles S: Expression of vascular endothelial growth family members in head and neck squamous cell carcinoma correlates with lymph node metastasis. Cancer 92: 556-568, 2001.

20. Shang ZJ, Li JR and Li ZB: Circulating levels of vascular endothelial growth factor in patients with oral squamous cell carcinoma. Int J Oral Maxillofac Surg 31: 495-498, 2002.

21. Cheng SJ, Lee JJ, Kok SH, Chou CH, Chang HH, Yang H, Chiang ML and Kuo MY: Expression of vascular endothelial growth factor is significantly associated with progression and prognosis of oral squamous cell carcinomas in Taiwan. J Formos Med Assoc 110: 50-57, 2011.

22. Hurwitz H, Fehrenbacher L, Novotny W, Cartwright T, Hainsworth J, Heim W, Berlin J, Baron A, Griffing S, Holmgren E, et al: Bevacizumab plus irinotecan, fluorouracil, and leucovorin for metastatic colorectal cancer. N Engl J Med 350: 2335-2342, 2004.
23. Seiwert TY, Haraf DJ, Cohen EE, Stenson K, Witt ME, Dekker A, Kocherginsky M, Weichselbaum RR, Chen HX and Vokes EE: Phase I study of bevacizumab added to fluorouraciland hydroxyurea-based concomitant chemoradiotherapy for poor-prognosis head and neck cancer. J Clin Oncol 26: 1732-1741, 2008.

24. Yao M, Galanopoulos N, Lavertu P, Fu P, Gibson M, Argiris A, Rezaee R, Zender C, Wasman J, Machtay M, et al: Phase II study of bevacizumab in combination with docetaxel and radiation in locally advanced squamous cell carcinoma of the head and neck. Head Neck 37: 1665-1671, 2015.

25. Ferrara $\mathrm{N}$ and Davis-Smyth T: The biology of vascular endothelial growth factor. Endocr Rev 18: 4-25, 1997.

26. Monk BJ, Sill MW, McMeekin DS, Cohn DE, Ramondetta LM, Boardman CH, Benda J and Cella D: Phase III trial of four cisplatin-containing doublet combinations in stage IVB, recurrent, or persistent cervical carcinoma: A Gynecologic Oncology Group study. J Clin Oncol 27: 4649-4655, 2009.

27. Wright JD, Viviano D, Powell MA, Gibb RK, Mutch DG, Grigsby PW and Rader JS: Bevacizumab combination therapy in heavily pretreated, recurrent cervical cancer. Gynecol Oncol 103: 489-493, 2006

28. Monk BJ, Sill MW, Burger RA, Gray HJ, Buekers TE and Roman LD: Phase II trial of bevacizumab in the treatment of persistent or recurrent squamous cell carcinoma of the cervix: A gynecologic oncology group study. J Clin Oncol 27: 1069-1074, 2009.

29. Suzuki S, Shimazaki J, Morishita K, Koike N, Harada N, Hayashi T and Suzuki M: Efficacy and safety of oxaliplatin, bevacizumab and oral S-1 for advanced recurrent colorectal cancer. Mol Clin Oncol 5: 391-394, 2016.

30. Fang J, Wang $\mathrm{H}$ and $\mathrm{Xu} \mathrm{Q}$ : Bevacizumab combined with low-dose S-1 as maintenance therapy with a long progression-free survival in an elderly patient with heavily pre-treated advanced gastric cancer: A case report. Biomed Rep 1: 239-242, 2013.

31. Yamada K, Ichiki M, Takahashi K, Hisamatsu Y, Takeoka H, Azuma K, Shukuya T, Nishikawa K, Tokito T, Ishii H, et al: A multicenter phase II trial of S-1 combined with bevacizumab after platinum-based chemotherapy in patients with advanced non-squamous non-small cell lung cancer. Cancer Chemother Pharmacol 78: 501-507, 2016.

32. Nie K, Geng C, Zhang L, Liu S, Zhang Z, Wang R, Zou X and Ji Y: Clinical observation of bevacizumab combined with S-1 in the treatment of pretreated advanced esophageal carcinoma. Chin Med Sci J 31: 221-227, 2016.

33. Yoshida M, Takagane A, Miyake Y, Shimada K, Nagata N, Sato A, Ogata Y, Fukunaga M, Otsuka K, Takahashi T, et al: A phase II study of third-line combination chemotherapy with bevacizumab plus S-1 for metastatic colorectal cancer with mutated KRAS (SAVIOR Study). Oncology 91: 24-30, 2016.

34. Weidner N, Semple JP, Welch WR and Folkman J: Tumor angiogenesis and metastasis - correlation in invasive breast carcinoma. N Engl J Med 324: 1-8, 1991.

35. Harada K, Baillie R, Lu S, Syrjänen S and Schor AM: VEGF expression in skin warts. Relevance to angiogenesis and vasodilation. Arch Dermatol Res 293: 233-238, 2001.

36. Fujita K, Sano D, Kimura M, Yamashita Y, Kawakami M, Ishiguro Y, Nishimura G, Matsuda $\mathrm{H}$ and Tsukuda M: Anti-tumor effects of bevacizumab in combination with paclitaxel on head and neck squamous cell carcinoma. Oncol Rep 18: 47-51, 2007.

37. Roland NJ, Caslin AW, Bowie GL and Jones AS: Has the cellular proliferation marker Ki67 any clinical relevance in squamous cell carcinoma of the head and neck? Clin Otolaryngol Allied Sci 19: 13-18, 1994.

38. Itashiki Y, Harada K, Ferdous $\mathrm{T}$ and Yoshida $\mathrm{H}$ : Effects of tumor necrosis factor-related apoptosis-inducing ligand alone and in combination with fluoropyrimidine anticancer agent, $\mathrm{S}-1$, on tumor growth of human oral squamous cell carcinoma xenografts in nude mice. Anticancer Res 27: 2365-2375, 2007.

39. Harada K: Supriatno, Kawashima Y, Yoshida H and Sato M: S-1 inhibits tumorigenicity and angiogenesis of human oral squamous cell carcinoma cells by suppressing expression of phoshorylated Akt, vascular endothelial growth factor and fibroblast growth factor-2. Int J Oncol 30: 365-374, 2007.

40. Shirasaka T, Nakano K, Takechi T, Satake H, Uchida J, Fujioka A, Saito H, Okabe H, Oyama K, Takeda S, et al: Antitumor activity of $1 \mathrm{M}$ tegafur-0.4 M 5-chloro-2,4-dihydroxypyridine-1 M potassium oxonate (S-1) against human colon carcinoma orthotopically implanted into nude rats. Cancer Res 56: 2602-2606, 1996. 
41. Yoshida M, Muro K, Tsuji A,Hamamoto Y, Yoshino T, Yoshida K, Shirao K, Miyata Y, Takahari D, Takahash T, et al: Combination chemotherapy with bevacizumab and S-1 for elderly patients with metastatic colorectal cancer (BASIC trial). Eur J Cancer 51: 935-941, 2015.

42. Cao S, Durrani FA, Toth K, Rustum YM and Seshadri M: Bevacizumab enhances the therapeutic efficacy of Irinotecan against human head and neck squamous cell carcinoma xenografts. Oral Oncol 47: 459-466, 2011.

43. Wang Y, Dong L, Bi Q, Li X, Wu D, Ge X, Zhang X, Fu J, Zhang $\mathrm{C}$, Wang $\mathrm{C}$, et al: Investigation of the efficacy of a bevacizumab-cetuximab-cisplatin regimen in treating head and neck squamous cell carcinoma in mice. Target Oncol 5: 237-243, 2010.

44. Gyanchandani R, Sano D, Ortega Alves MV, Klein JD, Knapick BA, Oh S, Myers JN and Kim S: Interleukin-8 as a modulator of response to bevacizumab in preclinical models of head and neck squamous cell carcinoma. Oral Oncol 49: 761-770, 2013.

45. Ferdous T, Harada K, Kin T, Harada T and Ueyama Y: Efficacy of schedule-dependent metronomic S-1 chemotherapy in human oral squamous cell carcinoma cells. Int J Oncol 43: 271-279, 2013.

46. CELL BANK Website: HSC-2 cell. Available from: https:// cellbank.brc.riken.jp/cell bank/CellInfo/?cellNo=RCB1945.

47. Takahashi K, Kanazawa $\bar{H}$, Akiyama Y, Tazaki S, Takahara M, Muto T, Tanazawa $\mathrm{H}$ and Sato K: Establishment and characterization of a cell line (SAS) from poorly differentiated human squamous cell carcinoma of the tongue. J Jpn Stomatol Soc 38 20-28, 1989 (In Japanese).

48. Heydar H, Mansouri K, Norooznezhad M, Norooznezhad F, Mohamadnia A and Bahrami N: Bevacizumab inhibits angiogenic cytokines in head and neck squamous cell carcinoma: From gene to the protein. Int J Hematol Oncol Stem Cell Res 12: $136-141,2018$.
49. Wary KK: Molecular targets for anti-angiogenic therapy. Curr Opin Mol Ther 6: 54-70, 2004.

50. Gimbrone MA Jr, Leapman SB, Cotran RS and Folkman J: Tumor dormancy in vivo by prevention of neovascularization. J Exp Med 136: 261-276, 1972.

51. Holmgren L, O'Reily MS and Folkman J: Dormancy of micrometastasis, balanced proliferation and apoptosis in the presence of angiogenesis suppression. Nat Med 1: 149-153, 1995.

52. O'Reilly MS, Holmgren L, Chen C and Folkman J: Angiostatin induces and sustains dormancy of human primary tumors in mice. Nat Med 2: 689-692, 1996.

53. Folkman J and Hochberg M: Self-regulation of growth in three dimensions. J Exp Med 138: 745-753, 1973.

54. Turley RS, Fontanella AN, Padussis JC, Toshimitsu H, Tokuhisa Y, Cho EH, Hanna G, Beasley GM, Augustine CK, Dewhirst MW and Tyler DS: Bevacizumab-induced alterations in vascular permeability and drug delivery: A novel approach to augment regional chemotherapy for in-transit melanoma. Clin Cancer Res 18: 3328-3339, 2012.

55. Iwasaki J and Nihira S: Anti-angiogenic therapy against gastrointestinal tract cancers. Jpn J Clin Oncol 39: 543-551, 2009.

56. Falcetta F, Bizzaro F, D'Agostini E, Bani MR, Giavazzi R and Ubezio P: Modeling cytostatic and cytotoxic responses to new treatment regimens for ovarian cancer. Cancer Res 77: 6759-6769, 2017.

(7) $(-)$ This work is licensed under a Creative Commons Attribution-NonCommercial-NoDerivatives 4.0 International (CC BY-NC-ND 4.0) License. 